\title{
PROJECT MANAGEMENT
}

\section{МОТИВАЦІЯ ПЕРСОНАЛУ ОРГАНІЗАЦІЇ ДО ОБМІНУ ЗНАННЯМИ}

\author{
Галина Анатоліївна Уткіна, кандидат економічних наук, доиент \\ Донеиький юридичний інститут МВС Украӥни, м. Кривий Ріг \\ ORCID: http://orcid.org/0000-0001-7513-4407
}

DOI: https://doi.org/10.31435/rsglobal_ijitss/30112019/6818

\section{ARTICLE INFO}

Received 14 September 2019

Accepted 11 November 2019

Published 30 November 2019

\section{KEYWORDS}

knowledge economy, management models, intellectual activity, motive, motivation.

\begin{abstract}
The article deals with the key issues of the motivation specificity of implementing the intellectual activity of the personnel in an organization on the basis of knowledge economics. The construction of a mechanism of motivation in an organization that would stimulate extremely constructive behaviour that builds effective communication to achieve a consistent result of the team was proposed. The author studied the aspect of the goal implementation of "readiness for knowledge exchange" through the triad of procedures motive motivation - an incentive to manage the knowledge of the organization, multiplication and transformation into a product of consumption.

Based on the analysis of a number of theoretical sources, the goal is to identify and approve the meaning of "active intellectual organization" ("intellectual activity") with the requirements of the production (of the society) based on competent economy and the possibility of its use as a measure of the intelligence formation of early transition to innovation.

The further development is given to the definition of what constitutes "intellectual activity" by providing two main components of the factors that are defined, determining the meaning of the term - the mental ability of each person and the motivation of their activities, and a clear focus on what each of these factors is the only necessity, but is not sufficient, and only the two together are necessary and sufficient for the generation of intellectual activity. Axiomatic method, methods of theoretical generalization and comparison, analysis and synthesis in order to clarify the meaning of "motivation" are used in the process of the study.
\end{abstract}

Citation: Galina A. Utkina. (2019) Staff Exchange Knowledge Motivation in Organization. International Journal of Innovative Technologies in Social Science. 8(20). doi: 10.31435/rsglobal_ijitss/30112019/6818

Copyright: (C) 2019 Galina A. Utkina. This is an open-access article distributed under the terms of the Creative Commons Attribution License (CC BY). The use, distribution or reproduction in other forums is permitted, provided the original author(s) or licensor are credited and that the original publication in this journal is cited, in accordance with accepted academic practice. No use, distribution or reproduction is permitted which does not comply with these terms.

Постановка проблеми. Сприйняття знань організації, отриманих за рахунок «колективізації» індивідуальних знань, як стратегічного ресурсу, породжує одну з важливих практичних проблем інформаційного простору: як примусити (надихнути, заохотити, спонукати тощо) до максимально добровільного бажання персоналу організації ділитися досвідом, нести знання у виробничий процес і отримувати від цього задоволення; як виховати потребу робити це завжди і системно. Цей аспект формування знань організації є однією 3 важливих проблем теорії знань організації і належить до основних проблем отримання знань в організації за рахунок горизонтального інформаційного потоку - знань, що «закупорені в пляшці», якою можна вважати кожного 3 персоналу організації. Оскільки такому процесу притаманно індивідуально-психологічний характер в формі інтелектуальної активності, то для якісного його забезпечення потрібно почати з носія таких знань, тобто з людини, як основної 
одиниці інтелектуального капіталу організації. Це в свою чергу стосується мотивів, якими керується носій знань.

Аналіз останніх досліджень і публікацій. Інтелектуальна активність може бути породженою різними мотивами, оскільки сенс мотивів визначається (задається) системою «індивідуум - середовище» в контексті існуючого соціуму відповідно до економічної парадигми. В цілій низці наукових досліджень, зокрема в працях закордонних вчених У. Буковича, Р. Ханта, Арджиріса, Ольве та вітчизняних Ю. Бажала, Т-Г Саблука, М.Я. МесельВеселяка, Л. Мармуль порушена спроба прослідкувати зміну сенсу мотивів на основі аналізу їх 3 позиції постіндустріального інноваційного суспільства і інноваційного суспільства на базі знаннєвої економіки. Цей результат для вітчизняних організацій представлено в формі побудови поки що гіпотетичної організації - «інтелектуальної організації». Саме в такій організації з'явиться реальна можливість свідомо максимально використати прояву інтелектуальної активності персоналу та переродження іiі в інноваційну активність. Це переродження не може (або недоречно чекати) бути спонтанним із-за часового виміру синергетичних процесів. «При такому підході до розуміння процесу отримання знань організації можливо припустити, що мотив задається таким цільовим станом відносин «індивідуум - середовище», які самі по собі (хоч би в даний момент часу) є більш бажаними або такими наявного стану» [7, с.33]. Таким чином, при розумінні поняття «мотив» як бажаного стану в межах відносин «індивідуум - середовище», можна визначитися щодо основних проблем психології мотивації.

Формування мети статті. Виокремити специфіку мотивації реалізації інтелектуальної активності персоналу організації на засадах знаннєвої економіки

Виклад основного матеріалу. Мотив (за змістом відносин «індивідуум - середовище») формується в процесі індивідуального розвитку людини як основа оцінки відносин в названій парі. Зміна суспільних відносин закономірно впливає на мотиви індивідуумів. Саме таку ситуацію маємо при переході на інноваційну діяльність, а потім при переході на таку діяльність на засадах знаннєвої економіки. В залежності від індивідуального розвитку людини в контексті середовища змінюється не лише перелік, зміст мотивів, а й їх ієрархічна привабливість. Саме це і визначає основний мотив діяльності на засадах знаннєвої економіки - успіх колективу організації у формі «отримання доданої вартості», як у вигляді грошових коштів, так i вигляді нарощеної інтелектуальної вартості. Цей головний мотив виробничої діяльності і визначає проблему актуалізації мотиву, тобто виникнення проблеми привабливості ситуаційних умов, що спонукають таку актуалізацію. Спонукання до дії певним мотивом розглядається як мотивація.

Викристалізовується проблема мотивації діяльності організації мотивом отримання доданої вартості за рахунок і тих знань персоналу, що є «законсервованими» в кожному 3 них (свідомо або несвідомо). Оскільки «розконсервація» персональних знань не є самоціллю, а $є$ лише складовою частиною процесу мотивації отримання нових знань за рахунок наявних знань i тих, які тільки що розконсервованих, то наступною задачею цієї процедури $є$ контроль за «поглинанням» цих знань в площині якомога ширшого дійового поля та обов'язкового використання їх далі. На думку німецького вченого, психолога Х. Хекхаузена [7], «мотивація розглядається як процес вибору між різними можливими діями, процес, що регулює, спрямовує дії на досягнення специфічних для даного мотиву цільових станів і таких, що підтримують цей напрям». При цьому мотивація не $\epsilon$ неперервним процесом, зміст якого визначено актом поведінки дійової особи. Така діяльність, на його думку, складається з різноманітних процесів, які здійснюють функцію саморегулювання на певних фазах такого акту.

Вид мотивації залежить як і в якому напрямку будуть використовуватися різні функціональні здібності індивідуума (вміння, навички, знання). Мотивація також $є$ основою для вибору між різними можливими діями, між різними варіантами сприймання, поясненнями інтенсивності та настирливість в здійсненні направленої дії і досягнення результату.

Якщо знову звернутися до практичної проблеми знаннєвої економіки - знаходження способів, методів «розконсервування» наявних індивідуальних знань персоналу 3 метою їх передачі іншим як таких, що тим чи іншим чином стають придатними для досягнення бачення організації, то потрібно мати механізм, який би гарантував вплив на джерело таких знань, тобто, спонукав носія потрібних знань «розконсервувати» їх і поділитися з іншими, а ці інші не просто їх привласнюють (поглинають і знову законсервують), а, об’єднуючи 3 своїми 
власними, трансформують в нові синергетичні знання. Для забезпечення неперервності ланцюга процесів «віддати знання - поглинати знання - синергетично відтворювати знання» потрібно мати певний механізм спрямування, впливу на поведінку кожного індивідуума як учасника процесу формування знань організації. Таку процедуру прийнято називати стимулюванням. «Стимулювання - це деякий вплив на людину, метою якого є іiї направлена діяльність скоригувати її поведінку»[2. С.40].

Кожна 3 процедур для отримання «родзинки організації» - знань організації в конкретній ситуації наповнюється певним практичним змістом і має певну форму (алгоритм, алгоритмічний припис, правила, види стимулів тощо). Оскільки конкретизація змісту цих процедур стосується певних індивідуумів, то важливими вимогами при їх формуванні повинні бути прозорість їх змісту, простота застосування та зрозумілість їх функцій, універсальність задуму. Це означає, що їх формування повинно грунтуватися на цілком визначених принципах, які поступово формує соціум, колектив організації та керівництво організації. Реалізація управління цими процедурами - це створення загального призначення системи мотивації отримання, розробка систем і шляхів доступу до індивідуальних знань персоналу як «родзинок» виробничого характеру, а тому така система повинна:

- спонукати персонал працювати на результат організації;

- реалізувати стратегію росту колективу;

- підвищувати ефективність за рахунок співробітництва.

Реалізація тріади <віддати - поглинати - відтворювати>, як конкретизація розробки системи мотивації, представляється різними функціональними формами відповідно до структурних рівнів: керівництво організації через обмін досвіду шляхом делегування; головні спеціалісти через систему тренінгів для середньої ланки менеджерів; виконавці виробничих процесів через наставництво під керівництвом середньої ланки менеджерів.

Щодо конкретного змісту процедури мотивації по отриманню знань організації, то він визначається відповідно до місцевих умов і специфіки виробничих відносин. Досить широкий огляд можливих наповнень змісту цієї процедури для отримання таких знань наданий в праці М. Мариничевої [3, с.22].

Враховуючи функціональне навантаження процедури мотивації як процесу, що спрямований в нашому дослідженні на досягнення специфічного мотиву «отримання організацією доданої вартості за рахунок неявних знань персоналу та нових знань як синергетичного об'єднання явних і неявних знань» та цільового стану «готовність персоналу до обміну знань», зосередимо увагу на основному векторі цієї процедури - на психологічній підготовці колективу до обов'язковості такого цільового стану та усвідомлення його практичної вагомості. Тобто, на створенні такого внутрішнього господарського клімату, який сприяє до обміну знань в потрібний час і в потрібному місці. Для реалізації цього необхідно:

створити умови для прозорості тієї інформації, пошук якої здійснюється на базі організації (РІЯ, окремих організацій/підприємств, об'єднань підприємств, в розрізі галузі); діяльність в цьому напрямку - зробити зрозумілою і обгрунтованою (моніторинг галузі, розробка бачення, обгрунтування місії; окреслення місця кожної організації в розрізі такого бачення, доведення до усвідомлення ролі кожного учасника діяльності в дусі перебудови галузі і управління організацією тощо). Бачення діяльності повинно бути виокремлено чітко, ясно, переконливо, прозоро, щоб забезпечити появу психологічної готовності до процесу обміну знань;

- обгрунтування і усвідомлення на цій основі кожним індивідуумом своєї вагомості в процесі реалізації бачення організації (індивідуальна значимість);

- культ організації: все для отримання позитиву організації відповідно до Основних правил успіху;

- повага до знань, як стратегічного ресурсу (системність і своєчасність інформаційних потоків щодо ролі знань);

- свобода слова, комунікацій та мислення;

- сформованість керівника як лідера руху;

- сформованість довіри і взаємного порозуміння як створення необхідних і достатніх умов для обміну знаннями.

Практичні форми обміну знань як ноу-хау: 
- участь в різних моніторингах систем об'єктів, окремих фактів, результатів діяльності тощо з метою подальшого використання результатів у виробничій діяльності;

- «колективне мислення» неофіційних виробничих груп;

- азарт, спонтанність, еврика;

- своєчасність презентацій нових знань, отриманих за рахунок обміну;

- поява постійної потреби в отриманні нових знань як критерію сформованості готовності до обміну знань.

Розглянута сукупність реально можливих мотивацій в умовах поточного стану вітчизняного суспільства як послідовності актів поведінки колективу організації, підприємства, господарства, спрямована на отримання знань та їх рекультивацію в умовах постійного руху та стресу. Процес управління ними $\epsilon$ свого роду джерелом отримання можливостей збільшення доданої вартості. Але це ще не є запорукою того, що будь-який член колективу гарантує свою участь в процесі обміну знань за рахунок своїх неявних законсервованих. Отже, виникла потреба забезпечення мотивації до обміну знаннями, тобто необхідність стимулювання цієї процедури.

Наповнення практичного змісту поняття «стимулювання», як впливу на персонал для коригування його виробничої поведінки, повинно бути таким, щоб наблизити реалізацію місії існування організації, з одного боку, а, з іншого, максимально забезпечити і відповідно оцінити інтелектуальну активність кожного робітника. Це можливо обумовити такими принципами:

- об'єктивність, яка проявляється, перш за все. за рахунок оцінки якості інтелектуальної активності, в формі актів:

- брати на себе відповідальність за кінцевий результат;

- самостійно розв'язувати проблеми в межах їх компетенції;

- творче підходити до розв'язання поставлених перед ним задач;

- ставити інтереси компанії вище власних інтересів;

- ініціювати удосконалення діяльності компанії;

- постійно підвищувати власний професіоналізм і компетентність;

- будувати відносини з компанією на основі лояльності.

Розмір винагороди кожного члену колективу повинен визначатися на основі об'єктивної оцінки результатів його праці з врахуванням інтелектуальної активності за принципами:

- прозорість персональної винагороди - робітник повинен знати, яка винагороду він отримає в залежності від результатів власної праці;

- адекватність - винагорода повинна бути адекватною трудовому вкладу кожного робітника в результат діяльності всього колективу, його досвіду та рівню кваліфікації. При цьому враховувати який вклад вносить кожен в підвищення ефективності компанії, підрозділу, як оцінюється якість роботи контрагентами, як оцінюється ступень вкладу співробітника;

- своєчасність - винагорода за працю повинна бути отримана якомога швидше (в матеріальній або не в матеріальній формі);

- вагомість - винагорода для співробітника повинна бути вагомою;

- справедливість - правила винагороди за працю повинні бути не лише прозорими, але й справедливими, перш за все, з погляду самого робітника.

Отже, побудувати систему стимулювання - це побудувати таку систему внутрішньогосподарських відносин, «яка викликала б гранично конструктивно поведінку, що забезпечувала ефективну комунікацію для досягнення сумісного результату діяльності колективу» [2, с.41].

Існують три основні типи стимулювання: матеріальні, нематеріальні, виробниченеобхідні, а також механізми впливу на робочий персонал: внутрішній (індивідуальний, особистий) і зовнішній (організаційний). Спеціалісти з питань стимулювання та організації виробничої поведінки переконані в тому, що лише внутрішні механізми (особисті мотиви) можуть реально бути основними факторами стимулювання, визначати інтелектуальну активність як основу інноваційної діяльності. Проте оскільки зміна парадигми інноваційної діяльності обумовлена зміною бази для капіталу організації (на знання організації) це визначило обов'язкову зміну сенсу особистих мотивів: змінюється зміст та форма інтелектуальної активності. Тому закономірна поява проблеми: «Що сьогодні може змусити працювати персонал з повною віддачею, тобто з максимально високим рівнем інтелектуальної активності?» Вчені і практики намагаються отримати відповідь на поставлену проблему. В 
багатьох дослідженнях виокремлюють певні системи погодженості шляхів розв'язання цієї проблеми. Серед них, зокрема це такі як:

- наявність свободи самостійних дій; можливість подальшого росту; динамічне керівництво;

- наявність в компанії чітких цілей і задач, гроші, розвиток компанії, згуртованість колективу;

- реалізація ідеалу співробітника (співробітник повинен бути оперативним, виконавчим, відповідальним);

- реалізація ідеалу керівника (підтримує ініціативи, лідер, ставить чіткі цілі тощо).

Поступова формується база концептуальних стимулів і механізмів впливу на персонал. Наприклад, досвід роботи цілої низки прогресивних компаній з погляду їх системної діяльності, спрямований на віддачу, персональних наявних знань організації/компанії і поглинання цього потоку знань та застосування їх, як «родзинки» в процесі виробничої діяльності. Зміст вже існуючих технологій розробки систем стимулювання визначає таке основне положення цієї процедури: чітке визначення цілей і задач нових процесів так, щоб персонал міг усвідомити, які саме показники їх роботи чи бізнес-процесу передбачається покращити за допомогою нових процесів і інструментів, що саме це їм дасть, тобто, створюються умови, коли інформація щодо стимулювання $є$ прозорою, а дії керівництва - зрозумілими.

Далі на основі детального моніторингу можливої і бажаної системи інтелектуальної активності колективу (персоналу, або його частини) проектуються виробничі ситуації та здійснюється їх індексація за певною школою. Формування стимулів передбачає детальне врахування інтелектуальної активності особи, що стимулюється тим чи іншим способом. Такий принцип стимулювання повинен бути колективним документом і бути прозорим за змістом, простим в користуванні та бути доступним за змістом. Щодо індексації, то вона повинна бути динамічною і обгрунтованою особливо в тих точках, які пов'язані з оцінкою якості основної виробничої діяльності.

Важливо при цьому те, що для посилення ефективного обміну знаннями та думками необхідно привчити співробітників спілкуватися один 3 іншим, перетворити інформаційний простір в простір комунікацій, стимулювати спілкування, розвивати культуру групової праці, впроваджувати виробничі ігри, широко використовувати всі види гласності для висвітлення досягнень за рахунок надбаних знань організації.

Все вищезазначене дозволяє виокремити основні шляхи комунікацій в колективі по забезпеченню обміну знань:

- цільові заходи, що спрямовані на передачу знань і досвіду колегам, взаємне навчання співробітників;

- виробничі комунікації, під час яких здійснюється обмін знаннями природнім шляхом в процесі спілкування, в ході виконання функціональних обов'язків;

- невиробничі комунікації, коли спілкування здійснюється в неформальній обстановці;

- комунікації з зовнішнім середовищем, яке складає не лише бізнес- середовище, але і інші аспекти спілкування персоналу.

Закономірна поява цілої низки робіт, в яких розглядається можливі аспекти зміни сенсу наповнення індивідуальних мотивів [1],[6]. До таких робіт відноситься матеріал статті І.Позина «9 речей які мотивують співробітників більш, ніж гроші» [4]. 3 посиланням на власний досвід автор виокремлює:

- щедрість на похвалу;

- наділення співробітників розширеними правами та можливостями, щоб вони могли працювати як єдина команда;

- трансформація ідеї бізнесу в власні ідеї співробітників;

- культура відносин між керівництвом і персоналом (конфіденційність відносин);

- ініціювання права на лідерство;

- відкрита і системна демонстрація заохочень;

- корпоративний відпочинок;

- психологічне «злиття» 3 колективом (розділяти з колективом успіхи та поразки).

Висновки. Розглянутий аспект реалізації цілі «готовність до обміну знань» через тріаду процедур <мотив - мотивація - стимул> дає право стверджувати, що управління знаннями організації повинно стати частиною філософії ії корпоративної культури, яка реалізується в такий спосіб: усвідомлення необхідності управління знанням організації іiі керівництвом; 
усвідомлення необхідності прикладення суттєвих зусиль організації до всіх процесів, в яких можна використати ці знання, бо лише в такому разі стане можливим обмін знаннями з метою отримання доданої вартості.

\section{ЛІТЕРАТУРА}

1. Букович У. Управление знаниями. Руководство к действию. М.: ИНФРА-М, 2002.113с.

2. Коваль А.Г. Мотивация и стимулирование персонала: основы построения системы стимулирования. Кадры предприятия. 2002. №7. С $39-45$

3. Мариничева М.К. Управление знаниями на $100 \%$ : Путеводитель для практиков. М.:Альпина Бизнес Букс, 2008. 320c.

4. Позин И. 9 вещей, которые мотивируют сотрудников больше, чем деньги. HR-сообщество $u$ публикаиии. URL: http://hr-portal.ru/article/9veshchey-kotorye-motiviruyut-sotrudnikov-bolshe-chemdengi (дата звернення 17.02.2019)

5. Славогородська О. Ю. Мотивація персоналу на підприємстві до підвищення компетентності як інструмент забезпечення конкурентоспроможності підприємств. Проблеми науки. 2010. № 1. С. 94.

6. Хант Р., Базан Т. Как создать интеллектуальную организацию. СПб. Питер, 2002. 230 с.

7. Хекхаузен Х. Мотивация и деятельность. СПб. Смысл, 2003. 860 с: ил.- (Серия «Мастера психологии»). 